\title{
DISCIPLINING CUSTOMERS AT THE GRAND SEASIDE HOTEL
}

DIRK BUNZEI

University of Keele

Department of Management

Keele University

ST5 $5 B G$

England UK

Email: d.bunzel@.keele.ac.uk

STEWART CLEGG

School of Management

University of Technology, Sydney

PO Box 123

Broadway NSW 2007

Australia

Email: s.clegg@uts.edu.au

GREG TEAL

Department of Management

University of Westem Sydney

Campbelltown NSW 2045

Australia.

Email:g.teal@uws.edu.au

\section{ABSTRACT}

The Grand Seaside Hotel is a large five-star hotel in an Australian Coastal town. It is a place that not only aspires to provide excellent service but that also seeks to reconcile two apparently divergent demands: the need for customized service and the efficient management of business operations. To commit staff to the provision of service excellence, management has introduced a customer service programme that relies on various forms of training and rewards, as well as a guest response system. The customer service programme, particularly the use of guest questionnaires, appear as disciplinary strategies that aim to produce service encounters in which both staff and guests are 'normalized'. The main loci of ethnographic data collection for this paper are regular Management Briefings. Through data collected from these. the paper investigates the use of the 'imaginary' in constituting service encounters and guest expectations. It interprets these in terms of Foucault's Panoptic analysis to identify the immanent mechanisms of discipline in these customer service programmes.

Key Words: power, surveillance, panopticism. customer service

\section{DISCIPLINING CUSTOMERS AT THE GRAND SEASIDE HOTEL}

There is no railway station near the Grand Seaside Hotei: it is only approachable by car or public transport, on roads that descend a hill down to the coastal resort. The Hotel dominates the resort. It is huge in comparison to the small houses and apartments that otherwise characterise the town, nestled in a coastal bay, lapped by the surf, a quintessential Australian country town by the sea. The hotel is so 'grand' in its scale that it is singularly inappropriate for the settled and smallscale streetscapes. Yet, with the grace, and sense of place, scale and purpose, that might characterise a Stalinist hall of culture in some benighted East European country, the Grand Seaside Hotel sits, squarely dominating the beach, whilst simultaneously ignoring it. It takes a while to work out, but the peculiarity of the Grand is that it seems back to front: where one might expect a sweeping entrance to take advantage of the view, there is nothing other than a brick façade, unbroken, unblinking and unfriendly. One has to go around the hotel, to the rear, to find the main entrance - the front door, so to speak.

So, having made the journey down the hill and round the rear. let us take the reader inside, into a world of "unparalleled service excellence." As we stride into the lobby we appreciate that, ethnographically, we have entered a world of familiar resources, where hotels divide into front of house (where service encounters take place) and back of house areas. The segmentation of settings for everyday interactions into public or front-regions and private or back-regions 
(Goffman 1969; Baumeister 1986) explores people's behaviour through metaphorical reference to the behaviour of actors in a theatre. The performances that actors give on stage differ crucially from their behaviour behind the scenes. In other words, people may play certain roles in front regions that are more or less detached from their self. whereas the behaviour displayed in the more private back regions, concealed from public perception, will be more authentic.

\section{CONSTITUTING NORMAL CUSTOMERS}

The frontstage/backstage segregation is one of the most crucial demarcation lines in hospitality. Backstage rituals are the keys to front stage performance. They enable hotels partially to sustain the customers' exclusion from certain aspects of the production process by confining their involvement to service encounters in processes that constitute normal customers. Customized service achieves the apparent match between customer preferences and production systems by controlling the behaviour and expectations of both employees and customers. Customers have to be constituted as such - and they must have manageable identities.

An important backstage ritual is the public reading of guest questionnaire responses that occurs in the weekly senior staff Briefing Meeting. Guest questionnaires, in conjunction with the Grand Seaside's reward and customer service training programmes, are used not only to establish role models for staff behaviour but also constitute a system for rewarding or punishing employee performance. Additionally, the system implicitly defines appropriate guest behaviour and expectations. By analyzing both the sequences of meetings, in particular the reading of the guest questionnaires. and the staff behaviour rewarded or punished, one can extrapolate an ideal-tvpical customer profile. This profile of the normal customer not only serves as an alter ego for staff in service encounters but it also provides the generalized other for the process of staffs' selfsubordination to the principles of service excellence.

There are many different types of complaints recorded by the questionnaires and entered into the logbook. Not all categories of complaint receive equal attention. Those that obtain most artention point up what the organization values as appropriate or desirable staff behaviour. They also reveal what management sees as appropriate and inappropriate guest behaviour and expectations. In this view, the different categories of guest complaints implicitly define appropriate behaviour and expectations for guests. The set of guest expectations categorized as valia complaints are those that, from an organizational point of view, express guest demands that may be justified by the (normal) context of service provision. For instance. guests can expect staff to be friendly and polite, that they will not be exposed to unacceptable noise, that all appliances work properly, and that the rooms will be clean and tidy. The same hoids true for valid complaints addressing ethically inappropriate behaviour. Although the normative frame of reference is not primarily that of the organization but that of the (external) life world, guests have a right to expect treatment according to those norms. Simultaneously, however, guests are expected also to conform to these norms.

On the other hand quasi-valid complaints do not easily lend themselves to a clear-cut (normative) classification. Rather, such complaints demarcate a 'grey-zone' with respect to organizational norms. A single complaint, for instance about queuing at the Breakfast Garden, does not qualify as a violation of justified customer expectations. Only when several guests, simultaneously or more often. diachronically, perceive the same incident as not meeting their expectations, will the hotel make amends. A further category comprises imvalid complaints. Whenever management identifies a complaint as invalid they regard the expectations underlying the complaint as unjustified. One can interpret invalid complaints as signalling inappropriate expectations on the part of guests. Hence, when guests complain about the quality of tea bags, the rigidity of times for check-in and check-out, or sometimes even the weather, their complaints conflict with the organization's (self-) understanding about what the provision of (normal) customer service ought to imply. In other words, invalid complaints clash with the organization's understanding of what a normal customer should be like, that is, what she or he ought to expect. but also how she or he should behave. 
Management Briefings exemplify how management classifies invalid complaints and stigmatizes them with a negative customer profile. The Duty Manager reported from the logbook that he was called to a room where people complained about a baby crying next door. When he knocked on the door nobody opened it, and after entering the room, he found a six-month-old baby left alone. He then left a staff member with the baby and went looking for the parents throughout the hotel. When he finally found the parents, they were having dinner at The Ocean and did not seem to be worried at all about their baby. The Duty Manager's report at the morning briefing caused general outrage about the negligent behaviour of the parents. One manager, Bill, epitomized the general perception by cynically commenting that: "Those parents should be given the 'Parents of the Month Award".

Similar to the processes, by which valid and quasivalid complaints implicitly establish the profile of an ideal-typical normal guest, invalid complaints allow for identifying particular forms of guest behaviour as abnormal. The profile thus created transmits a negative customer image: one of an unjustly complaining thus deviant guest. Consequently, we may distinguish two metacategories of guest: those displaying appropriate demands and behaviour, nomal customers, and those who hold unjustified expectations or display inappropriate behaviour, that is, irrational or deviant customers or, in hotel jargon: the troublemakers.

\section{"DOCTORS", "KIDS", AND OTHER "TROUBLEMAKERS"}

Staff constitute groups of guests known for violating the organization's expectations of normal guest behaviour and classify them accordingly. In the hotel jargon of the Grand Seaside, such abnormal customers are referred to as "troublemakers". One category of guests that has acquired a reputation among staff for being notorious troublemakers is "doctors". Those subjected to this classification derive much of their reputation from annual conferences of medical associations regularly held at the hotel. As one of the supervisors of the conference unit summarized, "they are really the worst". This stigmatization is closely linked to the fact that conferences of medical associations are often held over the weekend. which gives the attendees the opportunity to bring along their partner and children. The fact that doctors' families stay at the hotel causes considerable problems for staff. Another supervisor described the problems involved as follows:

While the parents are having a good time in the ballroom. those kids are running around here and there, and they scream and vandalize throughout the whole hotel. Last year I had five kids jumping and dancing on an antique table in the Lobby, with the table being severely scratched and damaged as a result. I mean, we're talking here of a piece that's worth about two thousand dollars! And when I went to the parents and asked them to look after their kids, they just said 'Oh, don't worry about the kids; they are just having a good time'.

It is hardly surprising, then, that any arrival of a group of doctors is announced in advance during the Management Briefings. Often, such announcements are made with an ironic undertone and responded to by equally ironic comments:

Sascha: We are going to have the annual health conference in again. That means we'll have a hundred and fifty doctors with kids and spouses at the hotel this weekend.

Some people add comments such as "Oh no!" or "Not again!"

Sascha: As we know from last year, this will be real fun! (Sascha stresses the term 'real' so that it clearly sounds very ironic.)

Apart from such well-known and clearly defined categories of troublemakers, management and staff also report more vaguely classified groups. The conference supervisors inform of incidents with guests that lead to such classifications. Sometimes the staff has to handle verbal or even physical assaults from guests. The job of the duty managers, in particular, is often rather dangerous. as they have to ensure security in and around the hotel, which may involve dealing with drunk and physically abusive guests. It is not surprising that 
staff working frontline develop informal classifications or profiles of guests and their typical, or sometimes peculiar, expectations and preferences. The classifications established by staff and/or management are not confined to particular individuals who are known as notorious troublemakers. As seen in the example of the doctors, such classifications may be applied. stereotypically, to whole groups of customers. In contrast to the doctors, who almost consistently exemplify the inversion of the (ideal-typical) normal customer, other classifications are more ambivalent. One such ambivalent category is that of "kids".

Children are well liked at the hotel. In fact, given the market segment established by the hotel, families with children represent one of the most targeted groups of customers. Therefore, the hotel offers many facilities tailored for the needs and wishes of children. There is, for instance, the ' $\mathrm{Kids}$ Club'. Daycare for children is provided and the hotel offers to arrange for a baby-sitter if so desired. Yet, simultaneously, children are seen as troublemakers: noisy, not only when left alone but also when in the company of their parents. There are places in the hotel such as in The Ocean. the hotel's five-star restaurant where the presence of children is regarded as inappropriate. Although children are not officially banned from these places, the staff will politely remind customers to consider the special atmosphere of the restaurant when guests with.children make their bookings. Usually though, it is left to the empathy of the parents to ensure the proper behaviour of their children.

Courtesy and respect for other guests are key arguments and, simultaneously, effective tools of legitimation for staff and management alike to secure obedience from guests for what is, essentially, a form of unpaid co-productive labour. The aesthetic dimension of service requires that customers actively play their part in the scenery, even if it is only by accommodating the volume of their talk to the local ambience or by dressing up appropriately, as the following sequence from another Morning Briefing demonstrates.

Kyle: Well, we had a quiet Saturday, but we had super comments about the Spring Ball. The whole event was super and especially the theming was excellent.
Bill: Yes. I think this was really super-duper. The boys and girls up there did a terrific job. The band was brilliant. I mean, they really got into it and people were dancing like mad. And all the people were very elegantly dressed. I'd say 80 per cent of the men had dinner suits.

Kyle: Yes, we had one guy who came in jeans and a T-shirt. At first, we were almost going to say something. But, you did not have to say anything. You could simply see how embarrassed that guy was and that he felt very uncomfortable. He also complained to his girlfriend, who apparently didn't inform him that he was supposed to wear a suit.

Elsa: But I mean, what did he expect? (She shakes her head as in disbelief.)

Bill: Well, and some of the blokes up there made funny comments: "Nice suit, mate!" and so on.

Bill's whole body was shaking in laughter. Many others were laughing as well.

Kyle: So, we did not have to say anything, you could really see he felt uncomfortable and embarrassed.

The image of the normal/deviant guest and other such categorizations provide staff with routine assumptions (scripts) concerning what customers can legitimately expect in the conduct of a normal service encounter. Such scripts help fill the gap constituted through the indexicality of any labour contact (Fox 1974), an indexicality that becomes even more complex in the provision of customized service. Given that the participation of customers in the provision of service is not just desired but indispensable, the performance of customers and that of staff poses a similar problem of coordination and control to the organization. From another perspective, then, we can conceptualiże such categorization processes and their outcomes as (part of) control strategies, identifying them as essentially political, infused with power. 


\section{CONTROLLING CUSTOMER SERVICE THROUGH DISCIPLINARY POWER}

One can describe the customer service discourse of the Grand Seaside. and, in particular, the processes of categorizing customers, as constituting a system of disciplinary power aimed at the self of both the customer and employee (Holloway 1991). In Foucault's view, discipline is not merely a mechanism to control or subject individuals. "Discipline 'makes" individuals; it is the specific technique of a power that regards individuals as objects and instruments of its exercise" (Foucault 1977. p. 170). The Grand Seaside routinely employs processes of normalization and spatial segregation as disciplinary strategies. The Hotel faces the complex task of providing customized service to their customers while conducting their business operations as effectively and efficiently as possible. The striving for service excellence that is seen by the hotel's management as the road to business success presupposes the creation of a match between customers' expectations and the service provided by staff. To the organization, the creation of a match between expectations and service provision translates into an issue of controlling the agency of both staff and customers.

\section{Normalization: Management by Identities}

As shown, the categorization of guest responses allows for revealing insights into the normative foundations of the organization. These categories not only allow evaluation of staff behaviour as appropriate or inappropriate according to organizational norms but also enable the classification of guests in terms of whether their expectations coincide with those of the organization. In other words, what these classificatory processes conjointly attempt is the establishment of nomal service encounters. They do so by subjugating people to a particular identity (Knights \& Willmott 1989; Holloway 1991). In short, in striving for normal service encounters, such processes produce normal guests and normal staff (Kondo 1990).

With Foucault (1977), we may identify the constituents of the customer service discourse of the Grand Seaside, such as rewards. training, or the guest questionnaires, as strategies of normalization. Simultaneously, disciplinary penalty focuses on non-observance, on "that which does not measure up to the rule, that departs from it", whereby " $(t)$ he whole indefinite domain of non-conforming is punishable" (Foucault 1977, p. $178 \mathrm{f}$ ). More precisely, disciplinary punisiment ought to be corrective so that it seeks not only compensation but should also include exercise and correction through training. Hence. "punishment is only one element of a double system: gratification-punishment" (ibid. 180). It is, therefore, a system that thrives on a "carrot and stick' principle so to speak.

When considering the situation at the Grand Seaside, one can clearly find evidence for disciplinary strategies in general and that of -normalization in particular. The aspiration for service excellence operates as a minimal threshold, to use Foucault's terms, as simultaneously representing a demand and an ideal to strive for. Hence, those behaving normally are differentiated further according to their achievements in service excellence. Discussion during the meetings centres on the two poles of exceptionally good or bad behaviour in service provision. Those performing exceptionaily well may even qualify for one of the employee awards of the hotel; those performing poorly may have to undertake additional training. Hence, the repeated reading of guest complaints and evaluations, the customer service training, the various staff awards, and the ceremonial events that stress the essential importance of customer service, can all be regarded as contributing to the creation of an ideal-type of service excellence. It is this that marks the boundary between normal and abnormal.

We should notice, though. that it is not only the staff that are compared, differentiated, hierarchized, and excluded, in short, who are normalized. As suggested customers also become subjected to such processes of normalization. Whereas those customers who express no complaints, or valid and quasi-valid complaints. about the service experienced are classified as normal guests, those who raise invalid complaints or fail to meet the organization's expectations of appropriate guest behaviour are stigmatized as abnormal or troublemakers. The expectations of 
the latter are either ignored, as during the Management Briefings, or they are (often promptly) brought into check when they, in the eyes of the organization, misbehave. Most often it will be staff that trigger corrective intervention; on other occasions. peer pressure from a fellow guest might do as well, as the poor guy who dressed inappropriately for the Spring Ball found out. Both staff and guests are subjected to disciplinary strategies that attempt to establish the normalcy of service encounters desired by the organization. Normal service encounters demand normal staff and guests.

Categorization, with its implicit comparing, differentiating, and hierarchizing of staff and guests, is not the only disciplinary strategy applied at the Grand Seaside that aims at normalization. Spatial strategies such as segmentation and exclusion are very effective disciplinary techniques as well.

\section{Segmentation and Exclusion: Spatial Aspects of Discipline}

The establishment of normal and abnormal behaviour or individuais is one of the most important mechanisms in disciplinary systems of power. To Foucault, such binary division and branding represents a "dualistic mechanism of exciusion" founded on a "constant division berween the normal and the abnormal, to which every individual is subjected" (1977, p. 199). In this sense, the branding of guests as "kids", "doctors", or "troublemakers" represents a subdivision of their classification in terms of normalcy. Children represent a class of abnormal guests that are loud, constantly chase around, vandalize hotel property, will - when not properly looked after - disturb other guests and spoil the atmosphere in the hotel's luxury restaurant. As Foucault (1977) explains using the example of (medieval) lepers or plague-stricken towns, dealing with abnormalcy implies hierarchy, observation, and surveillance in an attempt to separate or segmentize, that is, to analyze and distribute those that do not comply with the norm. We find traces of such separation and segmentation also at the Grand Seaside. As children have been identified as departing from the profile of the normal guest, they are put under constant control and supervision. This is either through their parents, who have to secure th children's compliance with the normal conduct o behaviour at hotels, or through professional staff such as baby-sitters or Kindergarten teachers, a the hotel. In each case, the children are subjectec to a certain discipline. Moreover, children are not just (informally) banned from certain areas of the hotel. they are also allocated a special area as their own domain: the Kids-Club.

From this perspective, many of the activities the hotel offers to children and other guests are, essentially, disciplinary strategies aimed at securing the functionality of the overall hotel operations by separating or segmenting the overall population of guests according to criteria of normalcy. That the classification of normai/abnormai does not in each case coincide with superiorinferior shows in the example of VIP guests. Such guests represent. in a different way to children, an abnormal type of customer. Their prominent status entitles them to a variety of special services (e.g. special time for check-in and checkout) that are not accessible to normal guests. Some VIPs are separated from ordinary guests by residing on the fifth floor, an area reserved for executive suites. Yet, some VIPs mingle with the crowd, which makes it more difficult for hotel staff to segmentize, that is, to mark and distribute these guests. To do so, staff will register those guests: their names, time of arrival, room number, preferences, and the special services they are entitled to receive. Hence, whether they like it or not, VIPs (as well as children) are marked with the stigma of abnormalcy.

In the light of the techniques employed at the Grand Seaside Hotel, one may even reconsider the architectural design of the hotel as baring traces of disciplinary strategies. In particular, the spatial (and temporal) division between front and back regions of the hotel is of relevance in this context. The separation of guests from operations in the back of the hotel prevents them from gazing at (and potentially influencing or even controlling) those aspects of the hotel business that management regards as organizational prerogative. not only in respect to sacred parts of the business, such as administration. Probably, no one would expect guests to look into the hotel's financial statements or books. This exclusion also 
applies to quite profane duties, such as the preparation of food, or the cleaning of rooms. The latter process indicates that the separation between front and back is not a purely spatial one. Guestrooms are public (front) areas only at certain times. They are usually cleaned in the morning after guests have left and before they return or new guests arrive. During that time, guestrooms become quasi-private (back) areas where guests are not particularly welcomed.

The fact that the boundary between front- and back-regions of the hotel is temporally variable indicates already that this spatial demarcation is not entirely fixed. We may instead envisage the borderline between public and private spheres as subject to conquest between guest and organization. As the hotel business is essentially about renting time-space to guests, we should not be surprised about the territoriality displayed on both sides. Ideal-typically, the hotel's interest is to rent time-space as efficiently as possibie, that is, to give away as little time-space as possible for the maximum rent. Guests, on the other hand, expect to get usage of the time-space rented as extensively as possible. That both positions do not necessarily coincide is obvious. The implicit tension between the interests of the hotel representatives and those of the guests explains why the times for check-in and checkout are so highly contested. Controlling the times for the check-in and checkout means controlling the space of the respective guestrooms and hence, the profit source of the business.

The division between public and private spheres of the hotel, however, matters in another respect. Frontline staff are almost constantly on display to guests. The Management Briefings. particularly in their discussion of guest questionnaires demonstrate that guests fulfil a controlling function in service encounters. The same role applies to fellow staff members, who frequently remind their peers of their inappropriate behaviour or their failure to meet the standards of service excellence, as we soon shall see in the section on Panopticism. Consequently, (front-line) staff will be subject to the gaze of at least three others: management, peers, and guesis.

Most of the visibility in service encounters at the Grand Seaside is bilateral. This is what distinguishes it from surveillance, which marks the transition to the most sophisticated form of disciplinary control, Panopticism. The front-desk is a point in case. It is constructed opposite to the entrance and surrounded by walls on three sides in such a way as to secure the rights of staff as those who see (first) without them normally being subject to the gaze of others whom they are not aware of. When entering the hotel guests may well see the staff at the front-desk, while, when leaving, they ultimately tum their backs on them. One may therefore contend that the frontdesk privileges the gaze of staff on guests.

Strategies such as normalization or the temporal/spatial structuring of service encounters seek to secure control of both agencies involved in the process of service production: (frontline) staff and guests. The front of house area. in particular, is one of (almost) constant bilateral visibility where staff and guest mutually adjust and control their behaviour in line with their perceived visibility. Control does not stop at this level. The process of imagination - which is brought about by symbolic means, and which lifs out or disembeds service encounters into an imaginary sphere - transforms bilateral visibility into surveillance and control into self-subordination. This process renders, at least potentially, the Grand Seaside into an (inverted) Panopticon.

\section{IMAGINATION AND PANOPTIC CONTROL}

One way of dealing with uncertainty in providing customized service is to establish categories of customer expectations and link them with respective staff behaviour. In the case of normal guest expectations, staff's natural friendliness and helpfulness, in conjunction with the training they have received, should suffice to please the guests. However, when a complaint occurs, the staff must interpret it with respect to its justification and, in case the complaint is judged as valid, they have to apologize and consider compensation for the guest. On such occasions, the interaction between staff and guests happens in real time, that is, staff receive feedback (demand) from particular (real) customers in respect to concrete (real) events. Hence, staff can (and in fact often must) respond to a (real) demand (external stimulus) at the time and place of its occurrence. 
During such service encounters in real time, staff can often control the success of their intervention, through the reaction of the guest. on the spot. Under these circumstances, staff engage in an interaction with guests, during which a (step-bystep) discursive negotiation of meaning and relating actions occurs. Most importantly, the interaction that takes place is that between real individuals in real time. The process of making sense of the interaction relies, therefore, on mutual feedback: a process in which guests assist staff in interpreting their wants and needs. Therefore, real time communication helps to overcome the uncertainty involved in interpreting what guests expect staff to do.

In addition to the service encounters happening in real time, there are other occasions when staff obtain clues from guests as to what they are supposed to do in service delivery. Most obviously, one can think of the guest questionnaires. In contrast to the service encounters, on such occasions when these are discussed, demands (and feedback) occur as temporally and spatially displaced from the actual event in question. In other words, staff may gain insights about what they did right or wrong in retrospect. Hence, guest questionnaires "tell" staff how they have done or what they should have done differently. Of course, such feedback is used for future adjustment of behaviour. Yet, the insights gained are temporally and spatially separated from the concrete context in which they arose. The guest questionnaires (as well as the logbook and the numbers) that are regularly read during the Management Briefings allow for the disembedding of service encounter.

The system of socialization has to prepare individuals for service encounters which ensure that these individuals know how to behave as a (normal) guest. In this respect, one may talk of the institution of the service encounter being vested with systems trust. Of course, the organization does not play a completely passive role in this process. We should note that mechanisms for disembedding service encounters have significance for the organization as a whole. Usually, a single event (encounter) will remain a rather private issue berween the staff and guests involved: it remains confined to the social context of its occurrence. This holds true unless staff tell other members of the organization about incident, which happens frequently during meetings. In this way the encounter is represen to those who were absent at the time and place its occurrence. However, the tools par excelle for disembedding service encounters are the gu questionnaires that render private into put affairs. When a member of staff reports on cert: incidents or when guests comment questionnaires, they render the (priva) experience of those encounters accessible to oth members of the organization. Alternatively, 0 may refer to this process as the sharing of priva experiences with the (potentially whol organization.

The lessons that one can draw from such share information, however, are somewhat ambiguou As these lessons refer to incidents that happene in the past. they are not directly relevant to futur behaviour. Rather, management will use suci feedback to adjust behaviour of staff for futur encounters fand occasionally to compensate the customer who complains). For insights gainec from guest questionnaires to be successfully applied in future encounters, they require contexts analogous to those of the original complaint. The lessons drawn from an idiosyncratic event will be very limited in their applicability towards future action, if there are not any analogies berween the original and future events.

It is at this point that trust again comes into play. The organization has to have a certain type of confidence, as Giddens (1990) characterizes trust, in the reproduction of (normal) service encounters. In other words, to use guest questionnaires for guiding future behaviour demands that the context of their application shows at least some analogies to the context of their generation. As such, the usage of guest questionnaires involves a conservative aspect and, as any disciplinary technique. favours the establishment of routines.

Given the linkage between past and future events, the de-contextualization achieved through guest questionnaires remains necessarily incomplete. For one to extrapolate lessons from one context to another involves entering the sphere of imagination. For instance, by drawing analogies from past to potential future behaviour staff and 
managers of the Grand Seaside commonly speculate about what a guest may or may not expect in a given context. Each representation has an imaginary element. as have the questionnaires representing guest complaints. The distinction between experiences received in encounters in real time and representations of the latter, such as guest questionnaires, should not lead one to accept a naive realist stance. The former mode of experience does not constitute real representations of an objective reality, whereas the latter are purely fictitious inventions. Even a distinction along first or second hand impressions is questionable. One never really deals with impressions but only classes of representation (Vorstellungen) (Castoriadis 1997, p. 326).

\section{Imaginary Service Encounters and Customized Service}

Guest questionnaires represent retrospective evaluations of customer encounters. The guests complaining did really participate in service encounters and they did perceive the respective encounter in a certain manner. This criterion of reality, however, does not hold equally true for all service encounters. In fact, as soon as guests do not respond directly, such as in face-to-face encounters, responses will always contain an imaginary element. However, frequently it is not guests who comment on service encounters, but staff or management. Such comments are based on imaginary guest expectations. They are imaginary, in a double sense. First, with respect to the persons involved. The expectations relate to imaginary guests and do not derive from concrete individuals. Second, with respect to the expectations in question. Hence, imaginary guest expectations are abstract and based on what members of management or staff perceive as what normal guest expectations would have been if they had transpired. The guests do not even have to be real. They may be merely hypothetical (imaginative), as the usage of a frequent grammatical conditional indicates: "This does not lead to a good impression. if guests are passing by". Such references to imaginary service encounters are common. Although such comments are most often uttered in a rather helpful voice. dropped like side-comments in conversations during meetings - " . . by the way, I just wanted to remind you of ..." - those addressed seem often embarrassed by these "helpful" reminders and usually respond in an apologetic manner. The fact that these reminders are uttered during the meetings, that is, publicly, makes them not only an instrument of (public) punishment. They are also a disciplinary technique: the peer pressure exercised by the meeting participants will almost inevitably trigger corrective action (Sewell \& Wilkinson 1992; Sewell 1998). In this sense such reminders are not only punishing, they are corrective. offering the failing individual a chance to "make up" and become once more a good and useful member of the Grand Seaside Family.

Frequently, the reminders point to the importance of the aesthetic side of the hotel business: somebody may see staff hanging around and chatting, which potentially threatens the aestheric aspect of the service experience. Not only must Grand Seaside staff manage their motivation, they must also manage the way in which they appear to be motivated (Hochschild 1983). Because of the deference involved, the service encounters are temporally and spatially disembedded. Hypothetical (imaginary) service encounters may be enacted anywhere and any time, not only when guests are present. In fact, imaginary service encounters are. per definition. marked through their absence. In other words, in representing the absent, imaginary service encounters are mechanisms for disembedding social interaction from its concrete temporal-spatial context.

Instead of relying on fixed scripts, which may or may not prove appropriate in real face-to-face service encounters, staff are expected to use their imagination to respond flexibly to the infinite number of demands that may arise from guest expectations. This makes staff imagination crucial for the organization: the proactive approach demanded from staff is based on the latter's social imagination (as to what expect and how to respond in service encounters). Simultaneously, it directs staff commitment away from the mere following of rules, typical in bureaucratic organizations. Active imagining asks for commitment, not obedience. It is not confined to the overt dispiay of conformity in the body, but seeks to reach into people's soul (Barker 1993; Townley 1994: Jackson \& Carter 1998; Sewell 1998). 
Organizations that claim to provide custonized service would not seem to be able to rely on standardization. To them, the match between customer expectations and service provision represents a much more complex problem. In the case of the Grand Seaside. it seems as if staff adapt (even proactively) their imagination to that of guests. This means, at least theoretically, that the uncertainty involved for staff is much higher. It is not up to guests to adjust their behaviour along pre-defined organizational norms, as in the case of McDonalds (Ritzer 1991). Instead, the normative expectations of guests shape staff conformance. Hence, there is a double normative commitment involved for staff. On the one hand they comply with organizational norms; on the other hand they have to anticipate and respond to expectations of guests, which acquire the status of quasiorganizational norms.

It is the prominent status that guests' expectations acquire in customized service encounters that makes it difficult for service organizations to achieve a fit between those expectations and staff"s (social) imagination. This constellation increases not only the importance of staff recruitment policies but also the training and education of staff. Although, as mentioned earlier, most employees working in frontstage positions are casuals at the Grand Seaside Hotel, most of these casuals are students either of the local Technical College or the nearby University. This fact seems to ensure that most of the staff engaging in service encounters has the necessary social skills (and imagination) to match the expectations of their clientele, the guests. It is not accidental, therefore, that most guests praise staff not for being expressively polite or obedient but for their "natural friendly attitude".

As far as training is concerned one can seriously question as to whether one can educate staff to display a natural and friendly attitude or whether organizations have to rely on recruiting people with the desired attitudes. However, the Grand Seaside spends a lot of money on training and education of staff. The hotel holds regular induction days and training on the job is still an important element of skill development. There are also training courses, such as in the proper serving of alcohol. that the hotel has to run to obey state legislation. However, customer service training at the Grand Seaside Hotel is less about changing upgrading employee skills than about stretchi staff's (social) imagination. According to the (ti hotel's customer service philosophy people wi the proper attitudes seem to require hardly as explicit directives as to how to behave. In the search for the appropriate attitude, the 'Grar Seaside sub-contracts apprentices through th mediation of an independent agency. Tho apprentices are employed by the agency an contracted out to the hotel. The advantage for th hotel lies in increased flexibility and choice. Nc only can the hotel choose among the bes employees, they can also send back an: inappropriate apprentices without having to engage in legal considerations.

When staff internaiise the philosophy of custome service, they seem only to require (enough) imagination to anticipate customer expectations and will respond intentionally (automatically) in the appropriate way. Total Quality Employees seem to provide a favourable resolution of management's battle for control of the production process (du Gay 1996; Sewell 1998). Issues such as conflict of interests seem excluded from this discourse (Deetz 1998). Instead, a general identification of staff with the organization's goals seems presupposed by management. The context is one of pressure from the external labour market (the hotel is the major employers in the region). Given the underlying fear of joblessness, as experienced during a previous restructuring process, the simple equation of business prosperity and job security seems to ensure the required degree of compliance and identification. Hence, why staff should strive for service excellence remains tacitly understated but also understood. Characteristically, the official negation of issues of power and interests that this mode of discourse displays is explicit, while the implicit and underlying reality is another story. In such an environment, there remains no place for collective representation of employee interests: as The Hotel General Manager says

We don't have any Union members in our hotel. We treat our people well! So, there is no need for any Union. And if we still find somebody .... (He speaks somewhat more carefully)... Well. we'll find a way to get them out (He puts on a big smile). 
We have seen that in order to achieve the provision of service excellence that management at the Grand Seaside so eagerly aspires to, they have to rely to a large degree on (front-line) staff's imagination to meet the expectations of customers. This constellation not only requires recruiting staff with the desired imagination but is also a process that applies to the acquisition of customers. It also implies delegating responsibility for the provision of service excellence to staff (and guests). In other words, the organization has to invest a certain amount of (systems-) trust into the generation of normal service encounters, which implies the matching of normal guest expectations with normal staff behaviour.

\section{Imaginary Service Encounters, Self- Surveillance, and Panoptic Control}

Both staff and guests are subjected to each other's murual gaze. Staff will normally realize that guests or management will gaze upon them. However, the introduction of a sphere or maginary service encounters and guests renders visibility into a trap. Imaginary service encounters imply a lateral invisibility. The gaze of the guest or the manager is no longer bound to presence. As the incidents reported above have demonstrated any one, at any time, could function as an imaginary guest and hence, exercise control qua his or her gaze. From this perspective, the situation of the average frontline worker resembles one of constant surveillance in which "(h)e is seen, but he does not see; he is the object of information, never a subject in communication" (Foucault 1977, p. 200). The implications of the lateral invisibility quite profoundly "induce in the inmate a state of conscious and permanent visibility" (Foucault 1977, p. 201).

By introducing an imaginary sphere, management transcends the temporal confines of the public space. Front areas are public spaces only at certain times, that is. when they are the location of service encounters. What Panopticism does. however, is to overcome the very temporality of the public sphere, rendering it into an (imagined) constant area of display. What counts for the temporal confines of public space. applies also to its spatial confines. In dress, even outside the spatial boundaries, one is never allowed to be off duty, like a member of a total institution.

\section{CONCLUSION}

We can conclude that the faceless gaze on which Panopticism thrives not only "automatizes and individualizes power" (Foucault 1977, p. 202) but it also transcends (organizational) time and space. It is the imaginary element that renders (traditional forms of) direct control into disciplining systems of surveillance. As Foucault expresses it: "A real subjection is born mechanically from a fictitious relation" (1977, p. 202). As Foucault has demonstrated such a constellation results in the internalization of control and the surveillance of individuals (staff) to the gaze of an (imagined) omnipresent 'Other". Hence, the shaping of staffs" (social) imagination through the Grand Seaside's customer service philosophy has a double aspect. It seeks to direct and stretch staff's imagination towards potential guest expectations, and it subjects their imagination to internalize the omnipresence of surveillance. Panopticism, despite being founded in an architectural design, derives its efficacy from the absence of any concrete 'physical' gaze. It depends on the internalization (imaginization) of the gaze, which renders control into selfsurveillance. In other words, Panopticism is not an architectural but a mental structure.

It is not by accident that Panopticism demands the introduction of an imaginary sphere through forms of symbolic management such as meetings and rituals. Essentially, Panopticism is a mental structure, dependent on a process of selfsubordination under the principle of (constant) visibility. As Clegg observed, the nature of surveillance is "less in the actual superintendence, more in the sheer impossibility of avoiding the observer's gaze" (1998, p. 35). As a result, power becomes "internalized . . . as subjects learnt to survey themselves, to be reflexively self-regarding as if under the ever present and watchful eyes of surveillance" (1998. p. 35). However. as McKinlay and Taylor (1998, p. 182) observe, the illusion of constant surveillance. which constitutes the efficacy of the Panopticon, requires at least periodical reaffirmation. The reminders untered during the meetings achieve precisely this reaffirmation: they reconfirm the (potential) omnipresence of the gaze. Significantly, both Panopticism and the symbolism underlying the process of imaginization thrive on absence! 
Whereas Panopticism derives its efficacy from the absence of any concrete gaze, symbolism mediates the absence of the thing (here: the gazer), as Saussure may have said. Consequently, when analyzing Panoptical systems of surveillance one cannot but address the symbolic means of their (re-)creation.

A number of conclusions can be drawn from our conceptualization of the customer service discourse as a disciplinary system. First, with the introduction of imaginary guests, categories of organizational membership tend to become extremely blurred (du Gay 1996). As mentioned earlier, the nature of service encounters renders customers almost automatically into partial emplovees of the service organization, as they have to co-produce the service experience. However, such partial membership even to imaginary customers. It is the introduction of imaginary guests and their equally imaginary expectations that shape employees' predispositions and, hence, pre-structure service encounters at the Grand Seaside Hotel. Under these circumstances, one may indeed talk of 'virtual organization'.

Second, management uses the reference to imaginary customer expectations as a legitimation strategy for management prerogatives. Ultimately, it is the customer, not management, who want staff to behave in a certain way. Management only supports staff in striving to please the customer. Hence, when directing staff, management seems only to translate or interpret customers' needs and wants. In this sense, one can interpret the discourse of customer service of the Grand Seaside as a disciplinary system that directs and controls employees while, by the same token. legitimising management prerogatives.

Third the introduction of imaginary customers renders the demands ensuing from (hypothetical and real) guests' expectations even more complex and unpredictable. Hence, the demands for the appropriate behaviour on the part of staff increase virtually ad infinitum. Potentially, management can render (virtually) anyone into a (hypothetical) guest either to legitimize management prerogatives or to demand obedience'commitment from staff. From this perspective, even apparently 'neutral' remarks uttered during the Management
Briefings appear in a different light. When the General Manager announces that "staff are expected to provide service excellence that is beyond expectation"; when he wants "people to talk to their friends and families about the service they have experienced in the hotel", he creates, consciously or not, a pool of hypothetical guests. Hence, the potential sources of service demands and evaluations, as well as instances of control, are virually unlimited and unlimitable.

Surveillance is instantiated by management as if it were all encompassing and omnipresent, as if virtually anyone, at any time, and anywhere, could be a customer and, hence, exercise control in the form of judgements about the service experienced. If that were so, the situation would almost mirror that of a Benthamite Panopticon, where those under surveillance can never be sure wherher they are subjected to the gaze of the guest: the guest could be anybody, the guest could be anywhere at any time - hence the widespread use of professional guests to check on hotel service and quality. Moreover, even if guests do not directly complain to authorities at the hotel, they still have friends or relatives to whom they can share their complaint. "We want to be known as a hotel where exceptional service is standard and standards are above expectation", as the General Manager says. In other words (guest or management) expectations can be unlimited and so will be the attempts to meet them! We have here a seemingly vicious circle of discipline. It is one that incorporates different forms of surveillance, as well as categorizing and individualizing those subjected to the customer service discourse. These things are done in an attempt to normalize both guests and staff. Via imaginisation, the discourse seeks to infiltrate people's souls - closure is affected when the subjects thus constituted identify with the identity appointed for them. Only in these circumstances is control rendered into self-surveillance, with normal guests taking on the status of a generalized other. The hotel, as a secular out-of-time experience, stands nonetheless, as an institution that seeks to be as total as those monasteries of old from which the form evolved. Surprisingly, in a world of commerce we find a duty of care for the secular soul in a remorseless discipline not of spirituality but of materiality. 


\section{R E F E E N C S}

Barker, J. 1993, 'Tightening the iron cage: Concertive control in self-managing teams', Administrative Science Quarterlv, vol. 38, pp. 408-437.

Baumeister, R.1986, Identity: Cultural change and the struggle for self, Oxford University Press, Oxford.

Castoriadis, C. 1997, 'Radical imagination and the social instimuting imaginary', in The Castoriadis reader, ed. D.A. Curtis, Blackwell, Oxford.

Clegg, S. 1998, 'Foucault. power, and organizations', in Foucault, management, and organization theory, eds A. McKinlay \& $\mathrm{K}$. Starkey, Sage, London.

Deetz, S. 1998, 'Discursive formations, strategized subordination, and selfsurveillance', in Foucault, management, and organization theory, eds A. McKinlay \& $\mathrm{K}$. Starkey, Sage, London.

du Gay, P. 1996, Consumption and identity at work, Sage, London.

Foucault, M. 1977, Discipline and punish: The birth of the prison. Penguin Books, London.

Fox, A. 1974, Bevond contract: Work, power and trust relations, Faber and Faber, London.

Giddens, A. 1990, The consequences of modernity, Polity Press, Cambridge.

Goffman, E. 1969, The presentation of self in everyday life, Penguin Press, London.

Holloway, W. 1991, Work psychology and organizational behaviour: Managing the individual at work, Sage London.

Hochschild-A. 1983, The managed heart, University of California, Berkeley.

Jackson. N. \& Carter, P. 1998, 'Labour as dressage', in Foucault, management, and organization theon; eds A. McKinlay \& K. Starkey, Sage. London.
Knights, D. \& Willmott, H. 1989, 'Power and subjectivity at work: From degradation to subjugation in social relations', Sociology, vol. 23 , no. 4 , pp. 535-558.

Kondon, D. 1990. Crafting selves: Power, gender and discourses of identity in a Japanese workplace, University of Chicago Press, Chicago.

Luhmann, N. 1986, Soziale șisteme: Grundriss einer allgemeinen theorie. Suinrkanp Tachenbuch Wissenschaft, Frankfurt/Main.

McKiniay, A. \& Taylor. P. 1999, 'Through the looking glass: Foucault and the politics of production ', in Foucault, management, and organization theory, eds A. McKinlay \& $\mathrm{K}$. Starkey, Sage, London.

Ritzer, G. 1991, The McDonaldi=ation of socien, Pine Forge Press. Thousand Oakes.

Sewell, G. \& Wilkinson. B. 1992, "'Someone to watch over me': Surveillance, discipline and the just-in-time labour process", Sociology, vol. 26. no. 2, pp. 271-289.

Sewell, G. 1998, "The discipline of teams: The control of team-based industrial work through electronic and peer surveillance', Administrative Science Quarterly, vol. $43, \mathrm{pp}$. 397-428.

Townley, B. 1993, Reframing human resource management: Power, ethics, and the subject at work, Sage, London. 


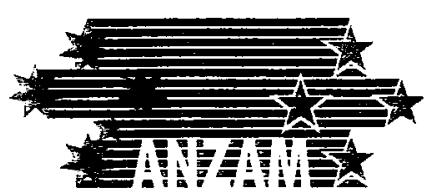

\section{Journal of the Australian and New Zealand Academy of Management Vol 8 No 22002}

\section{TABLE OF CONTENTS}

Disciplining Customers at The Grand Seaside Hotel

Dirk Bunzel. Stewart Clegg. Greg Teal

Career Plateauism: End of the Road or Just Another Fork?

Jacob Joseph, Bret Simmons, Kenneth Abramowicz. Tonia Girardi

Proposed Model for Investigating Relationships Between Vision Components and Business Unit Performance

Sooksan Kantabutra, Gayle C. Avery

Improving Confidence and Accuracy in Performance Appraisals

Paul L. Nesbit, Robert E. Wood

Management Education by Distance Mode: Combining Print and Computer Mediated Communication (CMC) Technologies to Provide Flexible Individual Study and Collaborative Learning Opportunities Ann Smith

Published by

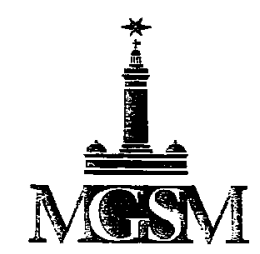

Sydney, Australia 


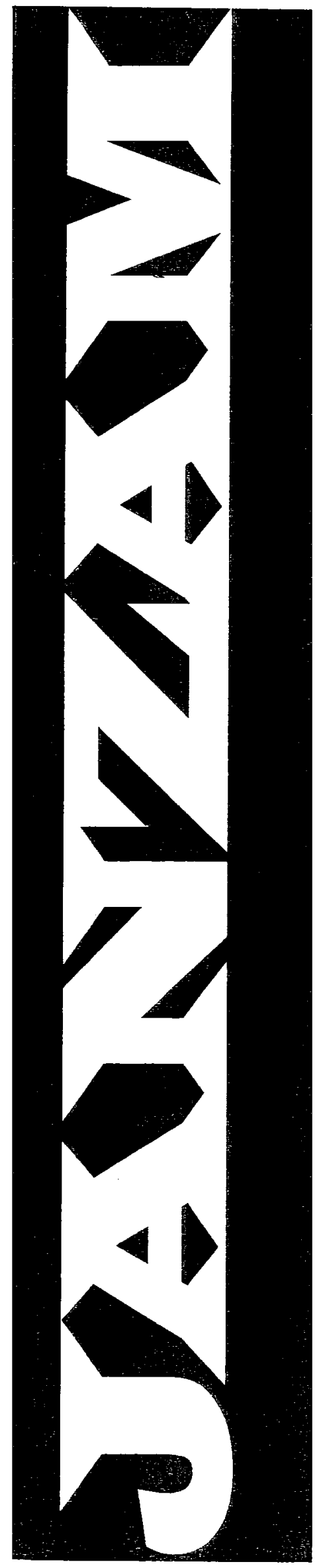

ISSN 1324-3209

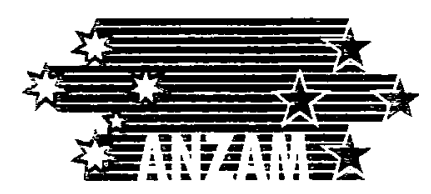

Vol 8 Number 2

Journal of the

Australian and

New Zealand

Academy of

Management 


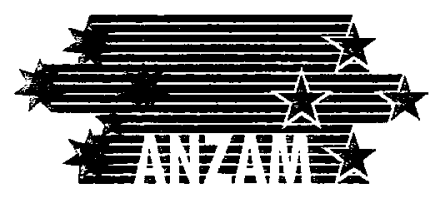

\section{Journal of the Australian and New Zealand \\ Academy of Management Vol 8 No 22002}

\section{TABLE OF CONTENTS}

Disciplining Customers at The Grand Seaside Hotel

Dirk Bunzel, Stewart Clegg. Greg Teal

Career Plateauism: End of the Road or Just Another Fork?

Jacob Joseph, Bret Simmons, Kenneth Abramowicz. Tonia Girardi

Proposed Model for Investigating Relationships Berween Vision Components and Business Unit Performance

Sooksan Kantabutra, Gayle C. Avery

Improving Confidence and Accuracy in Performance Appraisals

Paul L. Nesbit. Robert E. Wood

Management Education by Distance Mode: Combining Print and Computer Mediated Communication (CMC) Technologies to Provide Flexible Individual Study and Collaborative Learning Opportunities Ann Smith

\section{Published by}

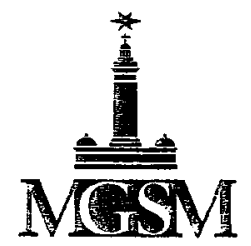

Sydney, Australia 


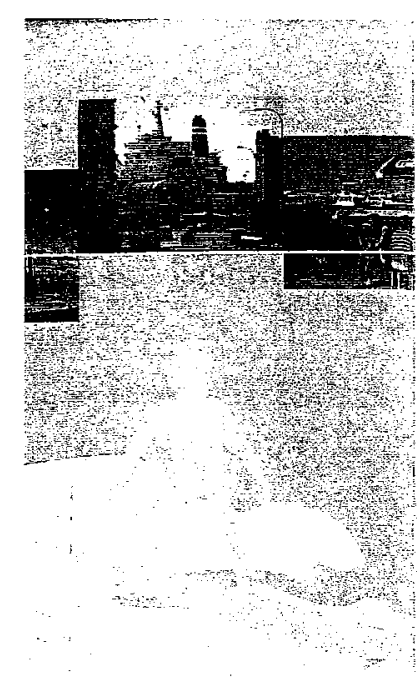

'conference/2003/anzam.

xhibition and

ship Dpportunities

bition featuring new and innovative its will be a key feature of the ance , numerous sponsorship tunities will be provided to iations that wish to take advantage xposure to conference participants.

\section{ind Accommodation}

ng to Perth is more offordable than zy think. Discounted fares within a are always ovailable. A range of modation will be booked to coter undgets and tastes.

rogram and Partmer

rence is not complete without the unity to socialise and network. A ie reception and conference dinner anned. A special program of as and tours will be offered to s.

\section{'Informạion}

al pr. am enquiries should be $d$ to Professor Alan Brown, Edith University, tel:-ól 892738278

il: alan.brown@ecu.edu.au.

or enquiries should be directed to ference organisers:

- Conventions Pty Ltd

3008784585

(890, Conning Bridge

RN AUSTRALIA 6153

i1 893322900

61893322911

promaco@promaco.com.au

iromaco.com.au/conference/

anzam

\section{JOURNAL OF THE AUSTRALIAN AND \\ New ZEALAND \\ ACADEMY OF MANAGEMENT \\ Vol 8 No 22002}

\section{TABLE OF CONTENTS}

Disciplining Customers at The Grand Seaside Hotel

Dirk Bunzel, Stewart Clegg, Greg Teal

Career Plateauism: End of the Road or Just Another Fork?

Jacob Joseph, Bret Simmons, Kenneth Abramowicz, Tonia Girardi

Proposed Model for Investigating Relationships Between Vision Components and Business Unit Performance

Sooksan Kantabutra, Gayle C. Avery 22

Improving Confidence and Accuracy in Performance Appraisals

Paul L. Nesbit, Robert E. Wood

Management Education by Distance Mode: Combining Print and Computer Mediated Communication (CMC) Technologies to Provide Flexible Individual Study and Collaborative Learning Opportunities Ann Sinith

Book Reviews

Notes to Contributors

Erratum 70 


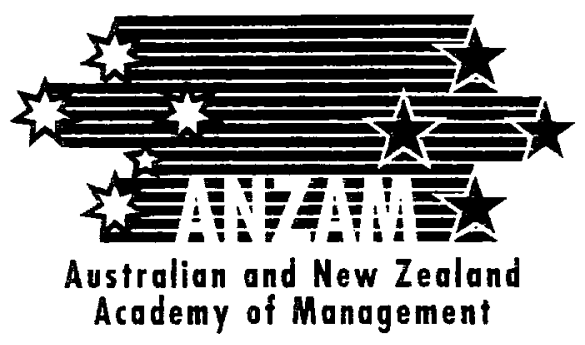

\section{Aims and scope}

The Journal of the Australian and New Zealand Academy of Management (JANZAM) seeks to publish academically rigorous papers that will advance knowledge on practical and theoretical aspects of management and the links between them.

Selection of papers for publication will be based on their relevance, clarity, topicality, individuality and interest to academics and practitioners. Areas to be covered in JANZAM reflect the breadth of membership of the Australian and New Zealand Academy of Management. However JANZAM also seeks submissions that import knowledge generated outside the field of management and outside the Australasian academic community.

JANZAM is published twice a year. In general, the first issue of the year will contain some of the best papers from the previous ANZAM Conference.

\section{Call for papers}

The Editor of JANZAM invites papers and articles for publication consideration, especially if conceptually original and innovative. JANZAM does not ordinarily publish more than one articale per author per volume, unless multiple authorship is involved.

All contributors are encouraged to submit manuscripts directly to the Editor.

\section{Subscriptions}

JANZAM (ISSN 1324-3209) is published in volumes of two issues. Volume 1 was published in 1995. JANZAM is free to all members of the Australian and New Zealand Academy of Management. Non-member subscritption rate is $A \$ 50.00$ per year plus GST and library subscription rate is $A \$ 100.00$. per year plus GST.

(C) Australia and New Zealand Academy of Management. All rights reserved. Fair use may be made of the contents of this journal for the purposes of personal study under the Australian Commonwealth Copyright Act 1968. 


\section{JANZAM}

\section{SUBSCRIPTIONS}

The Journal of ANZAM (JANZAM) has been published since 1995 (Volume 1) and in two issues per calendar year. It is provided to all current ANZAM nembers free. Subscription (two issues per year) prices* are quoted in $\mathrm{A} \$$ as following:

Personal Non-member $\$ 50.00$ plus $10 \%$ GST for Australian subscribers

Non-nember $\$ 50.00$ for overseas subscribers

$\$ 100$ for overseas subscribers

Back Copies $\$ 50$ plus 10\% GST per issue for Australian subscribers

$\$ \$ 50$ per issue for overseas subscribers

I would like to start my JANZAM subscription from (please enter year)

I would like to order back copies of JANZAM

(please specify volume and number of issues)

\section{Details of Subscriber}

Name:

Title:

Organisation:

Address:

Telephone:

Fax:

Email:

Contact details of subscription agent (if applicable):

Payment Method (all payments to be made in Australian dollars)

$\square$ Cheque/Money order enclosed - made payable to ANZAM

$\square$ Invoice (institutions only)

$\square$ Mastercard $\square$ Visa $\square$ Bankeard

Card Number

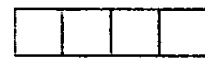

Expiry Date:

$$
\text { - }
$$

Amount: \$

Card holder's name (please print):

Signature:

\section{*All prices are subject to alteration without prior notice}

Please forward order(s) to: ANZAM Secretariat, c/o School of Management,

University of Technology, Sydney, Kuring-gai Campus, PO Box. 222, Lindfield NSW 2070, Australia

Phone: +61 29514 5582. Fax: +61 295145587 , Email: anzan@uts.edu.au, http://www.anzan.uts.edu.au 


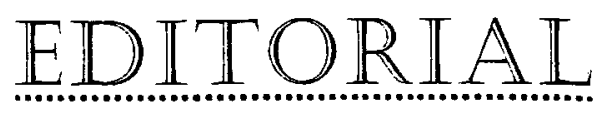

This is the first issue of JANZAM to be the responsibility of its new editorial team: Alan Brown. Rick Dunford. Gael McDonald and me. Although in some respects we are still finding our feet, we have focused over these first few months on the review process. Our aim is to give authors the best commentary on their papers that we can possibly manage and to do this as promptly as we can. We encourage reviewers to write developmental reviews, offering advice on how a paper might be strengthened. We have adopted the practice common in the leading journals of writing a detailed summary report to authors on the main issues arising from reviews. We hope that these efforts have been valuable to the authors who have offered papers for this issue. Our intent is that good reviewing experiences will encourage others to think of JANZAM as a vehicle for publishing their work, and will strengthen the papers that are published.

It is more and more apparent to us that a journal is far more than a series of volumes, and that its quality is the product of a broad-based effort in a community of scholars such as ANZAM to help each other with their work. The published papers are just one manifestation of that effort. We hope that you will let us know if you would like to contribute to the JANZAM effort as a reviewer. And we hope to attract your papers with a reputation for prompt. high quality reviews and editorial advice.

This issue probes the subtle realities of organisational life and the art of management in many different contexts. Jacob Joseph, Bret Simmons. Kenneth Abramowicz and Tonia Girardi push past the Peter Principle to ask what can be done to re-invigorate careers that have apparently plateaued. They encourage us to differentiate between a number of reasons for the phenomenon, and to recognise that each has its own distinct potential for the employee's future development.

Paul Nesbit and Robert Wood report a study on that most challenging of managerial roles, the appraisal of individual performance. With a carefully crafted research design, they demonstrate that frame-of-reference raining can improve the ability of performance raters against a control group. They suggest too that an important element in this improvement is the improved self-efficacy that raters experience during training. The benefit of training is, they suggest, not just an improvement in skill, but in raters' belief in their ability to apply the skill in practice.

In a similar vein, Sooksan Kantabutra and Gayle Avery explore the links that can be theorised to predict the performance impact of visioning exercises. They conclude that it is not just the elements of the vision itself that fosters performance improvements, but also a range of associated managerial actions that they call 'realization factors'. Here too, it is not just the abstract principle that has the effect, but also the means of its application.

And how do we train and educate people for these highly context-specific roles? Our traditional methods, especially for mature students, rely heavily on the sharing and contrasting of experience between people who know what works for them. But how can this be achieved for the many managers for whom distance education is the right choice? Ann Smith discusses the ability of computer mediated communication to create powerful communities of learning among students that are widely separated geographically.

Finally, Dirk Bunzel, Stewart Clegg and Greg Teal explore the choreography of a fascinating relational dance between the staff and customers of a large resort hotel. They show how the relationship is constituted by both guests and staff, and in particular how staff work to normalise their encounters with guests, defining for themselves what is, and what is not, normal guest behaviour. For me at least, hotels will never be quite the same.

We hope you will join our JANZAM relational dance, as a reader, reviewer and author. Possibly we will all find ourselves the subject of a future paper: "Disciplining Authors at JANZAM"? Or should that be Editors?

\section{Colin Campbell-Hunt}

\section{Editor}




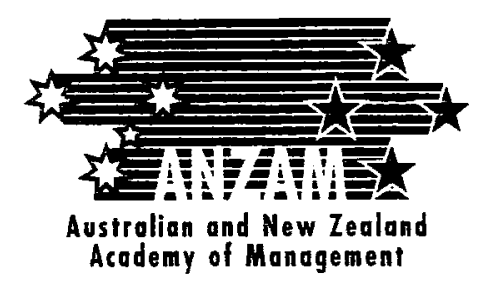

\section{EDITOR}

Professor Colin Campbell-Hunt

Department of Management

University of Otago

PO Box 56, Dunedin

New Zealand

Phone: $\div 6434798182$

Fax: +6434798173

Email: janzan@@business.otago.ac.nz

\section{ASSOCIATE EDITORS}

Professor Alan Brown

Edith Cowan University

Australia

Professor Richard Dunford

Macquarie Graduate School of Management Australia

Professor Gael McDonald

UNTTEC, Auckland

New Zealand

\section{BOOK REVIEW EDITOR}

Associate Professor Mary Barrett Griffith University

Australia

\section{EDITORIAL BOARD}

Professor Greg Bamber

Griffith University

Australia

Professor John Brocklesby

Victoria University of Weilington

New Zealand

Professor Alan Buttery

University of Western Sydney

Australia
Professor Peter Carroll

University of Tasmania

Australia

Dr Patricia Corner

Waikato Management School

New Zealand

Professor Patrick Dawson

University of Aberdeen

Scorland

Professor Peter Dowling

University of Canberra

Australia

Dr Murray Frazer

Frazer Consulting Pty Ltd

Australia

Associate Professor Bob Kane

University of Technology, Sydney

Australia

Professor David Lamond

Sydney Graduate School of Management Australia

Professor Gill Palmer

Monash University

Australia

Professor Paul Ryder

University of Newcastle

Australia

Professor Lawson Savery

Southem Cross University

Australia

Associate Professor Christopher Selvarajah

Royal Melboume Institute of Technology

Australia

Professor Alma Whiteley

Curtin University of Technology

Australia

Published by

Macquarie Graduate School of Management

Produced by

Dobson's Printing Pty Lid 